\title{
Influence of Indigenous Spiritual Beliefs on Natural Resource Management and Ecological Conservation in Thailand
}

\author{
Prompassorn Chunhabunyatip ${ }^{1, *}$, Nophea Sasaki ${ }^{1}$ [D, Clemens Grünbühel ${ }^{1}$, \\ John K. M. Kuwornu ${ }^{2}$ and Takuji W. Tsusaka ${ }^{1}$ (iD \\ 1 Department of Development and Sustainability, School of Environment, Resources and \\ Development (SERD), Asian Institute of Technology (AIT), Pathumthani 12120, Thailand; \\ nopheas@ait.asia (N.S.); clemens@ait.ac.th (C.G.); takuji@ait.ac.th (T.W.T.) \\ 2 Department of Food, Agriculture and Bioresources, SERD, AIT, Pathumthani 12120, Thailand; \\ jkuwornu@ait.asia \\ * Correspondence: noffon.npu@gmail.com; Tel.: +66-2-524-6378
}

Received: 21 June 2018; Accepted: 3 August 2018; Published: 10 August 2018

\begin{abstract}
Understanding how indigenous people manage their natural resources can provide a basis for formulating appropriate policies for natural resources management that benefits them while preserving their cultural beliefs. The objective of this study is to investigate the factors that influence the management of natural resources and the conservation of river ecology by the indigenous people in the Nongchaiwan wetland. We conducted in-depth interviews with 5 key informants and quantitative surveys with 158 households in two phases over a period of 3 years. Ancestral spiritual beliefs that are still salient in the Lower Songkhram River Basin influence natural resources management because they traditionally link people and natural resources. Such spiritual beliefs in the Lower Songkhram River Basin supported the indigenous people to continue conserving the natural resources in their territory. In addition, property rights granted to indigenous people also contribute to the conservation of natural resources. Our findings suggest that policy makers should engage with local beliefs in order to achieve sustainable resource management and, therefore, such practices should be recognized and included in the government's policies on natural resources management in locations, where indigenous people live for generations.
\end{abstract}

Keywords: sacred places; Don Pu Ta; local spirit; Lower Songkhram River Basin; property rights; punishment

\section{Introduction}

Almost all 17 Sustainable Development Goals (SDG) of the United Nations have stated the critical need for managing natural resources for poverty reduction, zero hunger, climate change mitigation, and importantly for achieving the SDGs themselves. Although there are various approaches to natural resources management, urging policy makers to take into account spiritual beliefs has increasingly attracted international attention because of their ability to effectively manage natural resources for generations. For instance, in some parts of India, religious beliefs have resulted in the conservation of sacred trees for generations [1]. Similarly, in Bangladesh, wildlife species such as the Black Soft-shell Turtle, Mugger Crocodile, Rock Pigeon and Rhesus Macaque have been protected for some generations because of local beliefs [2]. In some rural communities in Africa, natural resources were not only important as a source of food and other domestic products, but were the basis of cultural beliefs and, therefore, certain areas such as woodlands, water, and mountains were not to be abused and were considered sacred [3]. In the Lower Songkhram River Basin (LSRB), indigenous people believe in the 
natural gods and/or spirits having unique roles in regulating and using the wetland resources and express this through spiritual practices such as taboos, rituals, and zoning sacred places $[4,5]$. Engaging with spiritual beliefs for natural resources management has also been practiced from the past until the present day. Little detailed scientific research on indigenous beliefs, taboos, and rituals associated with natural resource management (NRM) has been completed to establish their significance [6]. Although management practices may be hidden in complex beliefs and may appear to have no scientific basis, many indigenous beliefs have been shown to be effective [7,8]. A number of peer-reviewed studies, including a focus on north-east Thailand [9], support this premise. Notably, establishing a direct correlation between the superior or inferior environmental state of wetlands and the existence of strong or weak communal spirituality is almost impossible, so indirectly achieving the objective through several avenues of innovative research by linking the spiritual domain and the material world is a product of numerous incremental approaches. The objective of this study is to investigate the factors that influence the management of natural resources and the conservation of river ecology by the indigenous people in the Nongchaiwan wetland. This collaborative research involving anthropology and ecology was completed to help explain the relationship between indigenous beliefs and NRM in the study area and other parts of the LSRB with the questions as to the type of belief system, the relationships between indigenous people and spirits, how the indigenous people use and manage natural resources in the wetland, and the rules and regulations for using natural resources in the restricted lakes and protected species. This study attempts to provide valuable insights into the changing values of indigenous beliefs in the context of management of natural resources and the effect of indigenous spiritual beliefs on NRM and ecological conservation.

\section{Indigenous People, Beliefs, and Natural Resources}

\subsection{Indigenous People and Natural Resources}

Indigenous people in some parts of the globe are entitled to specific rights to collectively use and manage natural resources, predicated on their historical, social and cultural connection to a particular territory. The United Nations (UN) defines indigenous people as people being inheritors and practitioners of unique cultures and ways of relating to people and the environment. Indigenous people have retained social, cultural, economic and political characteristics that are distinct from those of the dominant societies in which they live [10]. Following such traditional practices as beliefs, taboos, myths, and songs, the indigenous people of Ashanti communities in Ghana, for example, have been able to conserve their forests for generations [11]. Access to any sacred forests in Ashanti communities is governed by strict customs, which include the practice of rituals and sacrifices before obtaining the permission to harvest certain tree species. These practices could protect forest biodiversity and watersheds, certify existing forests, and prevent Ashanti people from overexploiting resources, resulting in better conservation of their forests [12,13]. Another example of indigenous peoples' practices is the use of beliefs in totems for managing the natural resources and conserving flora and fauna by the Ba'Aka pygmies of Central Africa. They believe that killing totems for food would bring a negative impact to their well-being. They also believe that hunting of the animals would prompt bad luck for the community. It is believed that pregnant women should not eat certain types of reptiles, birds and animals because eating them might stop production of breast milk or cause fetal abortions [14]. In addition, as some parts of rivers or streams and forests are considered sacred, and fishing and hunting are forbidden unless special rituals are to be performed [15]. Traditional practices in $\mathrm{Ba}^{\prime} \mathrm{Aka}$ demonstrate the existence of traditional strategies by indigenous people for conserving natural resources in some African communities.

In Chiang Mai (Thailand), Lua people were the first settlers in the Chiang Mai Valley over 1300 years ago [16]. Today they are embraced by the northern part of Thailand in the villages along the Thongchai Mountain [16]. Lua's traditional beliefs associated with operations in the swidden agricultural system are guided by animistic beliefs in every farming process. Their practices 
based on the traditional beliefs have demonstrated the ability to sustain agro-diversity and inherent wild biodiversity, ensuring ecosystem functions and supporting livelihoods and food security [17]. In another example, the Black Tai Tribe in northern Vietnam performed management and conservation of natural resources as guided by their beliefs in the spirits of the forests [18]. The Black Tai Tribe living in the "holy" forest performed ancient rites and rituals where they worshipped the spirits of their ancestors. They believed that the "holy" areas were the place where their god resided. Consequently, the villagers respected and maintained the forest resources. In addition, two ethnic groups, the Bosis and Grusi, in northeast Ghana performed spiritual belief systems through sacrifices and worships to the ancestral spirits or gods [19]. These aspects of indigenous belief systems that rest on the attribution of supernatural powers to some parts of the natural environment as the home of the gods seem to have significantly contributed to conservation and protection of essential natural resources such as groves, ponds, soil fertility and animals from overutilization and exploitation, and their use explicitly encourages conservation of environmental resources [19].

\subsection{Indigenous People and Indigenous Beliefs in the Lower Songkhram River Basin (LSRB)}

In north-east Thailand, Kettate, Boonyong [9] studied the spiritual beliefs and a place where god resides called Don $\mathrm{Pu} \mathrm{Ta}$, concluding that the Don $\mathrm{Pu} \mathrm{Ta}$ is a sacred place for the community. The indigenous people respected the spirit and conserved the sacred area respectfully. The Don Pu Ta area remained natural, surrounded by big trees with a thick forest and a close relationship between nature and the indigenous peoples in the region. The relationship between the ethnic groups in the northern regions, such as the Hmong, Akha, Mien, Lue, and Lua peoples with the forests in the mountain regions was also studied [20]. The research found that the indigenous peoples who deeply respected the spirit would respect nature. They showed evidence of their beliefs through practicing rituals and worships. For, example, the Akha people that live in the forest follow rites to worship the guardian spirit by performing tree ordination and not allowing indigenous people in the village to cut the trees in sacred places, similar to the spiritual belief in Don $\mathrm{Pu} \mathrm{Ta}$ of the indigenous people in north-east Thailand, and especially the indigenous people in the Lower Songkhram River [21].

Many sacred places around the LSRB are called Don Pu Ta, but one of the most notable places is the wetland called Nhongchaiwan with an area of $0.96 \mathrm{~km}^{2}$ [22]. The wetland is an important part of a unique ecosystem because it is the last largest Cephalanthus tetrandra fresh water swamp forest in north-east Thailand [22]. The wetland is also an important site for the culture and identity of the indigenous people because it is a place of community for social activities, and generates income for the whole community [23]. The wetland is the source of biodiversity, providing food and herbs to the community. In the wetland, an island exists within a floating forest. This is an important place for fish breeding, and a shelter for fish to lay eggs when they migrate in the flood season from the Mekong River, which is useful for the indigenous people and other communities, not only in the LSRB, but also in the Lower Mekhong Greater Sub-Region [24].

\section{Methodology}

\subsection{Study Area}

For this study, Ban Don Daen village was selected as a case study site to represent indigenous people and the influence of indigenous beliefs on NRM in the LSRB. The village and communities were purposively selected through a ranking scaled from 1 to 5 , where 1 is the lowest rank and 5 the highest, with the following criteria used for selection: (1) Age/size of sacred lake and accessibility of the site (site has strict taboo, limiting access only to the "initiated few"). Accessibility in terms of topography of the terrain is also a strong consideration for safety reasons. (2) Existence of extractives within or close to the boundary. (3) Clan/community within the same region without extractive industries. (4) Representative villages of different eco-zones (i.e., marsh forest zone and inland flood forest zone). (5) Presence or absence of endemic, vulnerable and threatened biodiversity (i.e., species of 
traditional, national and regional conservation interest). (6) Government and external actors' interest in the community (for instance tourism site, development projects). Unlike the other places located in the Taborsongkhram Sub-District, Srisongkhram District of the Nakhon Phanom Province is near the selected site (Figure 1).

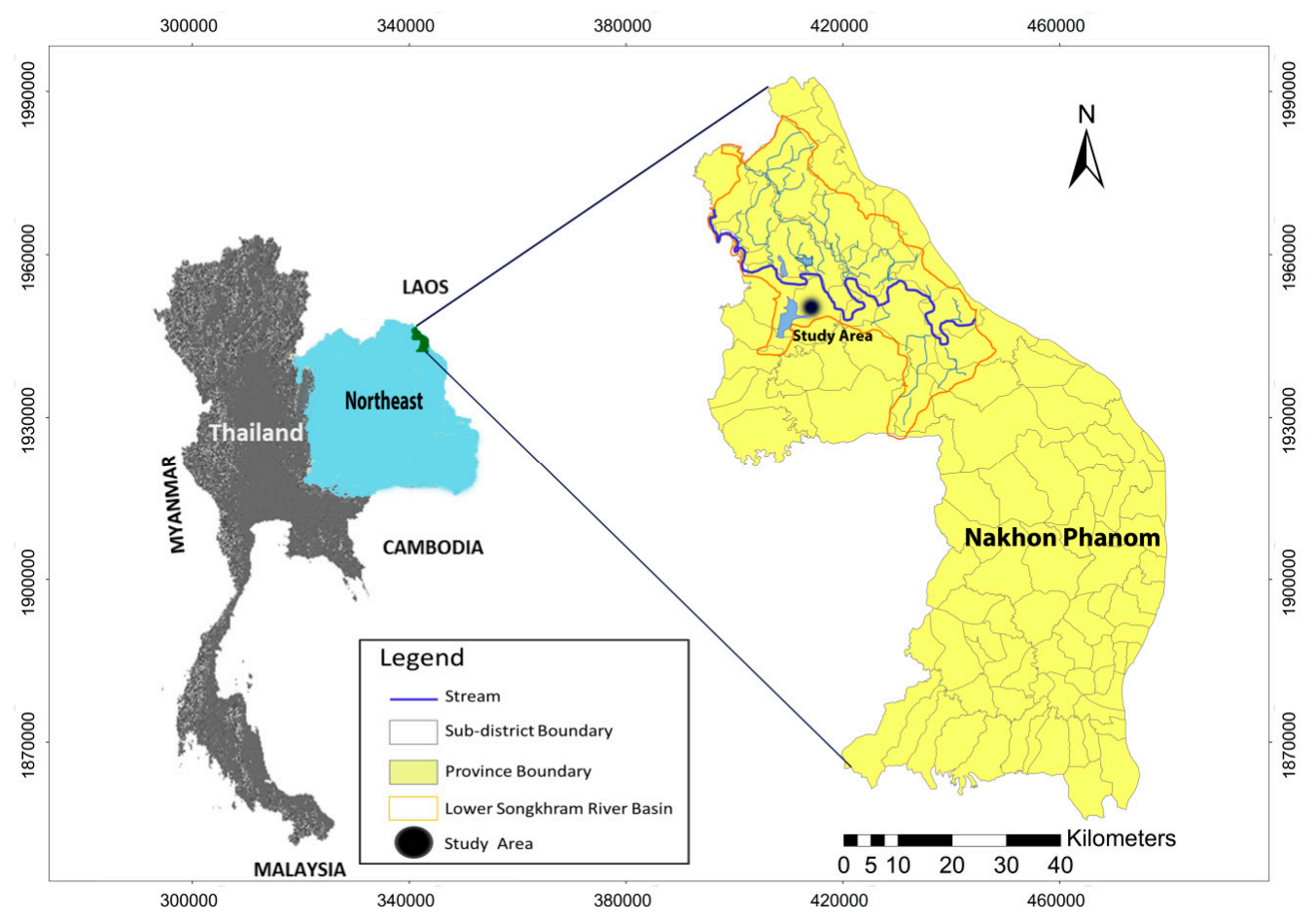

Figure 1. Location of the study area.

Ban Don Deang village was established approximately in the early 1800s and the majority of its indigenous people had emigrated from Lao People's Democratic Republic (PDR) because the Ban Don Daeng village had plentiful natural resources, especially near the water sources of the wetland and Songkhram River [21,22]. The village calls the wetland the "Nongchaiwan wetland", which is the main water source for the community. It supported the community during the flood season, allowing for the growth of double-crops. In the dry season, the water level is approximately $50 \mathrm{~cm}$ deep and increases to approximately $2-4 \mathrm{~m}$ in the rainy season [22]. The Nongchaiwan wetland includes four important ecological areas: marsh, swamp, swamp forest, and open water covered with aquatic weeds. In addition, the wetland provides natural resources for the community, which included an aquatic nursery with several fish species, which is also the main source of income. The middle of the lake contains cluster dominant plants in an area of approximately $0.96 \mathrm{~km}^{2}$ called the Chaiwan Tree (Cephalanthus tetrandra (Roxb.) Ridsd. and Bakh. f.), which is the only endemic species available in this wetland [22]. Consequently, the World Wildlife Fund (WWF) implemented a biodiversity conservation project to protect flora and fauna in this wetland in 2015.

\subsection{Data Collection}

Data collection was completed in two main phases to ensure that the data were collected systematically and allowed for analysis from the first phase before starting the second phrase.

\subsubsection{First Phase-Survey and In-Depth Interviews}

This phase elicited the cultural context and characteristics of the indigenous people. To build patterns and theories, visits were made to the participants. The household survey collected information from 158 randomly selected respondents on the characteristics of indigenous people, such as age, 
education features, occupation, indigenous beliefs, belief system and the use of wetland resources for subsistence purposes. The sample represented the communities' indigenous beliefs and natural resources, while the survey used closed-ended questions to generate multiple choice responses.

Moreover, information and qualitative data were obtained through semi-structured in-depth interviews and narratives recorded from five relevant individuals along with five key informants, namely, the village's leader, the village's shaman, and three elders. The interviews were conducted while observing and recording information with a focus on their physical and cultural characteristics and language used during the interviews.

\subsubsection{Second Phase-Qualitative Anthropology Research}

\section{In-Depth Interviews}

The second phase was completed with further in-depth data collection and was conducted over a three-year period from 2013 to 2015. The participants involved in the qualitative sampling included senior men and women, while younger men and women were selected as representatives of the communities to reflect the majority of the phenomena being studied, and to provide rich narratives for thorough in-depth interviews. The interviews were conducted at fishing sites or at homes of the participants after the day's work. A series of recorded interviews with the chosen participants were held in the communities visited. A semi-structured interview format was used as a tool to capture the thoughts of the participants in their own domain, which allowed us to further investigate how the people's world views influenced their relationship with natural resources. An interview script was also used with the following sets of questions: (1) oral history, (2) natural resource use, (3) sacred lakes and the community, and (4) general issues, particularly relationships with other communities and external actors. These questions helped the research find the changing patterns in technology and beliefs, which were the information that this research seeks. Oral history was used to make visible the history of groups whose views were hidden or marginalized, as for example in feminist studies of history [25]. People often recall critical occurrences in their lives in relation to other events or in their experiences with others [26].

\section{Focus Group Discussions (FGDs)}

The focus group discussions (FGDs) provided a platform for validating or testing some of the theories about the impacts of indigenous beliefs on NRM. Groups were segregated by gender and age to minimize the potential for domination by certain groups. The FGDs were interactive sessions, as group members recalled events and elaborated on the research topic. However, to maintain proper within-group interactions and ensure active participation from all group members, the seasonal calendar was used as a participatory tool. The FGDs were derived from the thematic patterns obtained by analyzing the individual in-depth interviews and participant monitoring in the first phase. The sequence of question topics that guided FGDs was:

\section{Belief system:}

a. Type of belief in the community.

b. Relationships between indigenous people and spirits.

c. Rituals, practices, and processes of beliefs.

2. Natural resource use:
a. Different types of natural resources.
b. Users and division of labor.
c. Boundaries and restrictions on natural resource use.

3. Wetland resource management: 
a. Wetland type.

b. Useful resources and significance for livelihood within wetland types.

c. Challenges and problems in the wetland area and influence on livelihood.

d. Community response to challenges.

4. Indigenous beliefs and sacred lakes:
a. Restricted lakes and protected species.
b. Reasons for and importance of restrictions.
c. Groups responsible for these lakes.
d. Fishing practices within these lakes and other lakes.
e. Groups to which these restrictions apply.

\subsection{Data Analysis}

Data management and analysis were conducted in four steps.

Step 1 Data were coded from the in-depth interviews and FGDs in the form of narratives or free flowing texts to outline the perspectives of the people. The context and the words used were considered important for exploring the factor influencing the NRM and ecological conservation in the particular wetland. Therefore, text was not fragmented as was the case for word counts. Word count analysis was not considered either in the context in which the words occurred, nor whether the words were used negatively or positively [27].

Step 2 The terms and phrases in Step 1 were grouped into categories and labels assigned for easy retrieval used with the triangulation technique to facilitate data validation. This step highlighted the belief system's influence on NRM and ecological conservation in the wetland.

Step 3 Recurrent phrases were noted to identify general patterns and to compare texts by using content analysis, due to quantifying patterns in communication, in a replicable and systematic manner [28].

Step 4 Responses obtained from the multiple choice questions were coded categorically and data were analyzed with descriptive statistics and multinomial logit regression estimation to examine the socioeconomic attributes of the beliefs. Multinomial logit regression is a statistical modeling approach used for predicting outcomes based on the values of a set of predictor variables [29]. It is a popular statistical modeling approach used to examine whether and to what extent included factors (socioeconomic profile) affect outcomes (perception) [30,31]. In this study, the dependent variable is the respondents' perception of wetland resources, which has three categories: 1. a source of livelihoods, 2. a place of worship, and 3. an inheritance from ancestors. The multinomial logit regression with the sample households is specified as follows:

$$
\begin{aligned}
& \ln \left[P\left(Y_{i}=1\right) / P\left(Y_{i}=3\right)\right]=\beta_{10}+\beta_{11} X_{1 \mathrm{i}}+\beta_{12} X_{2 \mathrm{i}}+\ldots+\beta_{1 \mathrm{k}} X_{\mathrm{ki}} \\
& \ln \left[P\left(Y_{i}=2\right) / P_{i}\left(Y_{i}=3\right)\right]=\beta_{20}+\beta_{21} X_{1 \mathrm{i}}+\beta_{22} X_{2 \mathrm{i}}+\ldots+\beta_{2 \mathrm{k}} X_{\mathrm{ki}}
\end{aligned}
$$

where subscript $i$ denotes the $i$-th household in the sample, $P\left(Y_{i}=K\right)$ is the probability of the outcome $K(K=1,2,3), \beta_{K 0}$ is the intercept term, and $\beta_{K 1}, \beta_{K 2}, \ldots, \beta_{K} k$ are the coefficients associated with explanatory variables $X_{1}, X_{2}, \ldots, X_{k}$. It should be noted that the estimated coefficients do not directly indicate the marginal effect of the corresponding explanatory variables on probability $P\left(Y_{i}=K\right)$ of the outcome. Rather, the coefficients reflect the marginal effect of the corresponding explanatory variables on the log odds ratio $\ln \left[P\left(Y_{i}=K\right) / P\left(Y_{i}=3\right)\right]$. A positive coefficient $\beta_{K k}$ means that the $\log$ odds increases by $\beta_{K k}$ as the corresponding independent variable $X_{\mathrm{k}}$ increases by one unit. However, it is possible to interpret the coefficients qualitatively in terms of both odds $P\left(Y_{i}=K\right) / P\left(Y_{i}=3\right)$ and probability $P\left(Y_{i}=K\right)$ of the outcome, given the relationship between $P, P\left(Y_{i}=K\right) / P\left(Y_{i}=3\right)$ and $\ln \left[P\left(Y_{i}=K\right) / P\left(Y_{i}=3\right)\right]$. 
It can be shown that $P\left(Y_{i}=K\right) / P\left(Y_{i}=3\right)$ is a monotonically increasing function of $P\left(Y_{i}=K\right)$, and $\ln \left[P\left(Y_{i}=K\right) / P\left(Y_{i}=3\right)\right]$ is a monotonically increasing function of $P\left(Y_{i}=K\right) / P\left(Y_{i}=3\right)$ [29]. Consequently, if the log odds $\ln \left[P\left(Y_{i}=K\right) / P\left(Y_{i}=3\right)\right]$ are positively (negatively) related to an independent variable, both odds $P\left(Y_{i}=K\right) / P\left(Y_{i}=3\right)$ and probability $P\left(Y_{i}=K\right)$ of the outcome are also positively (negatively) related to that variable. The only difference is that this relationship is linear for the log odds and non-linear for odds and probability of the outcome. The coefficients in the logistic regression are estimated using the maximum likelihood estimation method. The explanatory variables included in the multinomial logit regression for this study are defined in Table 1.

Table 1. Explanatory variables used in the multinomial logit regression.

\begin{tabular}{ll}
\hline \multicolumn{1}{c}{ Variable } & \multicolumn{1}{c}{ Description } \\
\hline Women dummy & 1 if the respondent is a woman; 0 otherwise \\
Age $40-59$ dummy & 1 if the respondent's age is between 40 and $59 ; 0$ otherwise \\
Age $\geq 60$ dummy & 1 if the respondent's age is 60 or above; 0 otherwise \\
University dummy & 1 if the respondent graduated from university; 0 otherwise \\
\hline
\end{tabular}

\section{Results and Discussions}

\subsection{Characteristics of Indigenous People}

\subsubsection{Socio-Economic Profile}

The major economic activities included paddy rice cultivation, fishing, aquaculture, maize cultivation, and animal husbandry. The dominant livestock were cattle and swine. The average annual income per capita was USD 1654 (Thai baht/rai 1 USD $=$ THB 35, 1 rai $=0.16$ ha). The male to female ratio in the sample was 1:0.8.

\subsubsection{Distribution of Respondents' Age}

The villagers within the working age bracket (20-59) were the most common for both men and women, followed by those over 60 years old (Table 2).

Table 2. Distribution of respondents' age $(n=158)$.

\begin{tabular}{ccccc}
\hline \multirow{2}{*}{ Age Bracket } & \multicolumn{2}{c}{ Male } & \multicolumn{2}{c}{ Female } \\
\cline { 2 - 5 } & No. & \% & No. & $\%$ \\
\hline $20-29$ & 17 & 19.3 & 5 & 7.1 \\
$30-39$ & 8 & 9.1 & 7 & 10.0 \\
$40-49$ & 17 & 19.3 & 26 & 37.1 \\
$50-59$ & 25 & 28.4 & 16 & 22.9 \\
60 and above & 21 & 23.9 & 16 & 22.9 \\
\hline Total & 88 & 100 & 70 & 100 \\
\hline
\end{tabular}

Source: Authors' field survey, 2015.

\subsubsection{Education}

A primary school is present in the village with 10 teachers, 109 students, one nursery with two babies, and 30 children. Most (86\%) of the respondents had graduated from secondary school, whilst $58 \%$ had graduated from high school (Table 3). On the whole, men's educational attainment was greater than women's. 


\subsubsection{Occupation}

The primary occupation of the residents in Ban Don Deng was agriculture. Agricultural production included paddy (rice), maize, and watermelon. Fallow by contractors and animal husbandry were practiced by 40 out of the 158 households. Traditionally, most villagers fished for subsistence, though in 2015 only $31.7 \%$ of the villages harvested fish as a main occupation. Weaving mats made from reeds was the secondary occupation that generated income of about USD 3-5 per mat.

Table 3. Distribution of respondents' educational attainment $(n=158)$.

\begin{tabular}{lcccc}
\hline \multirow{2}{*}{ Highest Level of Education } & \multicolumn{2}{c}{ Male } & \multicolumn{2}{c}{ Female } \\
\cline { 2 - 5 } & No. & $\%$ & No. & $\%$ \\
\hline Primary School & 12 & 13.6 & 14 & 20.0 \\
Secondary School & 21 & 23.9 & 19 & 27.1 \\
High School & 32 & 36.4 & 21 & 30.0 \\
University & 23 & 26.1 & 16 & 22.9 \\
\hline \multicolumn{1}{c}{ Total } & 88 & 100 & 70 & 100 \\
\hline
\end{tabular}

Source: Authors' field survey, 2015.

\subsubsection{Religion, Culture, and Tradition}

The household survey result shows that $53.3 \%$ of the villagers were Tai Yo Ethnic Group and the other $47.7 \%$ were Tai-Lao. Both groups were Buddhist and two temples were situated in the village. The in-depth interviews revealed that rituals, traditions, and events of the religion of Ban Don Deng were important for the way of life all year round. The Tai Yo Ethnic Group and Tai-Lao also celebrated all the events together in the village. In particular, Bun Duen Sam was an important event where all the villagers had to perform a ritual to their guardian spirit every year.

\subsection{Wetland Resources for Subsistence}

According to the survey, the indigenous Ban Don Daeng people used natural resources from the Nongchaiwan wetland in many ways: $90 \%$ used wetland water for agricultural irrigation, $87 \%$ used the water for consumption, $72 \%$ used the wetland for crop farming and gathering non-timber forest products (NTFPs), $66 \%$ for fishing, $25 \%$ for raising cattle, and $12 \%$ for cultivating aquatic animals such as leech and shrimp for distribution (Figure 2).

(\%)

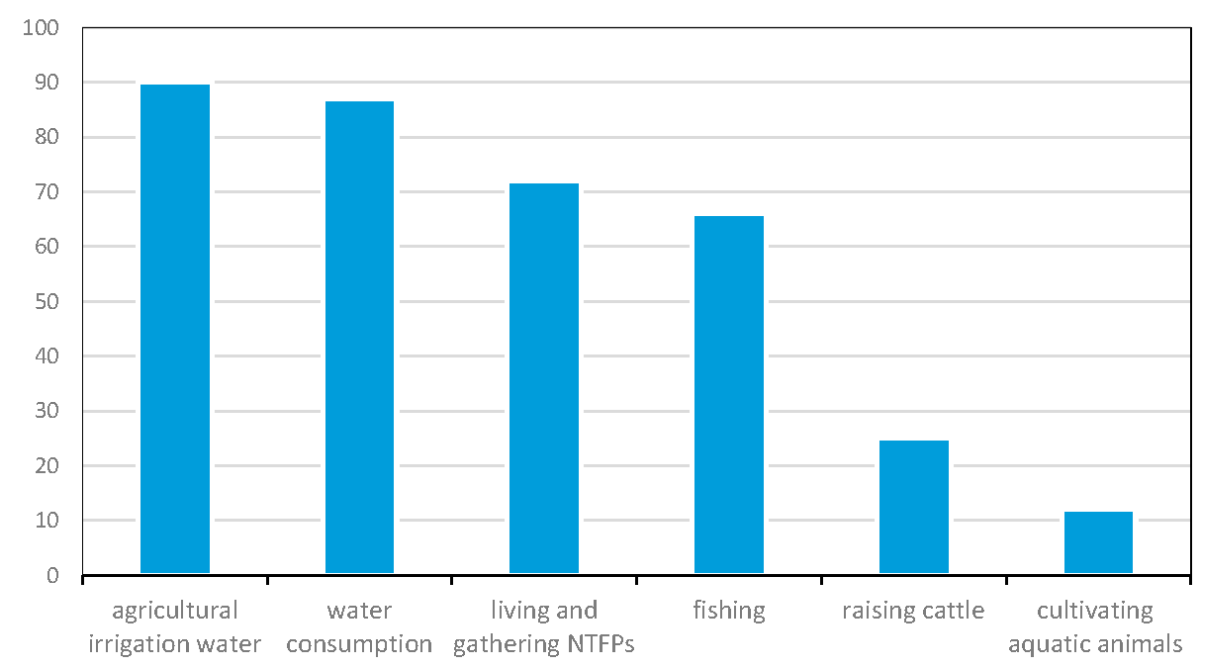

Figure 2. The proportion of indigenous people using the spiritual wetland resources for different subsistence purposes. ( $n=158)$. Source: Authors' field survey, 2015. 
The result from FGDs also found that the indigenous people allocated wetland resources for subsistence purposes by dividing it in periods of use of wetland resources year-round (Table 4).

Consequently, the wetland contributed to securing local livelihoods. The wetland resources at the site were important for the villagers who lived in and around the wetland. The wetland was also a habitat for other aquatic and bird species. Fish-spawning grounds existed in the deep pools and ponds during the dry season, and the fish then traveled to upstream tributaries to spawn during the wet season.

Table 4. Wetland resource use calendar.

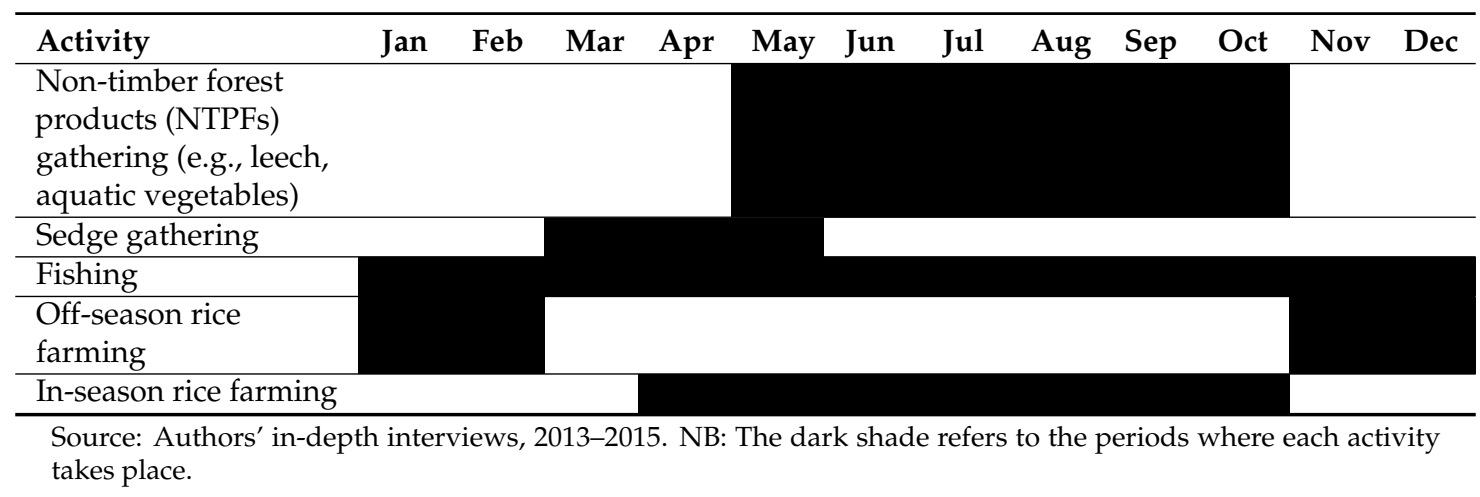

\subsection{Indigenous Beliefs}

\subsubsection{Spiritual Beliefs}

The result of our in-depth interviews with the five key informants, namely, the village's leader, the shaman, and three elders shows that the indigenous people of Ban Don Daeng believed in spirits (animism) as did their ancestors. They believed in the spirits of the indigenous people in Ban Don Daeng, from the basin to the south, and accordingly managed the natural resources in the Nongchaiwan wetland. The story of the wetland of the indigenous people was founded on the worship of the $\mathrm{Pu}$ Ta spirit. For good fishing, the villagers always worshipped the Pu Ta spirit first, praying for a good living and food. They would say "Pu Ta, I ask for fish for dinner, please". However, the indigenous people used their resources for sustenance only and did not use more than they needed for own consumption because they were considerate of the holy spirit that protected the Nongchaiwan wetland. To pay respect to $\mathrm{Pu} \mathrm{Ta}$, villagers worshipped the spirit on every Buddhist Holy Day in the middle of the lunar month by gathering flowers, incense, and candles at Chao Chum's house. Chao Chum was the shaman who was the mediator and transmitted messages between the $\mathrm{Pu}$ Ta spirit and the villagers. The villagers brought red flowers to Chao Chum' house, and then Chao Chum would bring all the red flowers from the people in the community to worship at the $\mathrm{Pu}$ Ta shrine on the edge of the Nongchaiwan wetland. The reason the villagers brought red flowers to worship the Pu Ta spirit is because an ancient story tells that red flowers are the spirit's favorite flower. The Pu Ta spirit's shrine was where the rite of Don Pu Ta, Ban Don Daeng occurred. This place was in the natural forest environment, and an area was set aside as an animal sanctuary in the Buddhist monastery. As it was believed that the sanctuary was guarded by the Pu Ta spirit, it had become a sacred area, where fishing was not allowed. Being a venerable spirit, the villagers repayed $\mathrm{Pu}$ Ta for their protection through an annual ritual called the Third Months ceremony. The indigenous people fed the Pu Ta spirit every year on the third day of the third waxing moon. By the lunar calendar, this was the New Year's Day of the ethnic groups in the village. Every household in the community gathered to perform this ceremony to worship the Pu Ta spirit. If any community member had to work outside the local area and could not participate in this ceremony, then they would send money as compensation. 


\subsubsection{Indigenous Beliefs in Auspicious Time Calculation}

The indigenous people of Ban Don Daeng also believed in auspicious time calculation. That might result in the success of a particular action, such as choosing the auspicious time for making a fishing tool and the right time for fishing. When there was no auspicious calculation, they felt nervous and unstable. Auspicious time calculation was adopted from Au Ba Kong Book, which is commonly used in north-east Thailand. For example, auspicious times included Sunday early morning, Monday late morning, Tuesday midday time, Wednesday afternoon, Thursday evening, Friday early morning, and Saturday late morning. This auspicious calculation occurred among the villagers who believed that this method would bring them lifelong sufficient fishing. Local beliefs and superstitions influenced the villagers' livelihoods. The strong faith in the Pu Ta spirit and auspicious time was believed by the villagers to ensure well-being from good deeds, and the feeling that the indigenous people would be blessed and have good luck. Local people found 124 species of fish in the wetland base, but more species could be found because of the large area of the study site. These species of fish were important in the interpretation of the productivity of the wetland and the effectiveness of the indigenous people in managing the area.

\subsubsection{Indigenous Beliefs Related to Taboos}

The regulation or prohibition is called a taboo, as part of the belief in the $\mathrm{Pu} \mathrm{Ta}$ spirit. Strict adherence to former ethical codes passed down by founding fathers to the present-day members of these societies is expected. From the household survey result, Buddhism was the only religion in the village (100\% of the population). However, from the in-depth interviews and FGDs, two types of beliefs coexisted within the present setting of these villages: a belief in the spirits and a belief in Buddhism. Although differences existed, the two ideologies were synchronized to maintain customary institutions that were based on traditional belief institutions perceived to be beneficial to the community, showing that traditional beliefs influenced indigenous life in this society and the way the community related to natural resources.

Consequently, the institutional belief system evolved to act like a demonstrator of the belief system and an intermediary for transactions between $\mathrm{Pu} \mathrm{Ta}$ and humans. Humans and $\mathrm{Pu}$ Ta were thought to communicate via dreams, as explained by an elder, "... the villagers who didn't bring the red flowers to worship Pu Ta on the Buddhist Day, Pu Ta will come to their dream for warning them to do worship on the next Buddhist Day". In other words, the belief in Pu Ta included the worship or method of service, constituting an institution that acted like a visible force in the area surrounding the institution. As explained by the village leader, in reference to fishing in Nongchaiyawan wetland, "If you want a lot of fish, you have to tell him before you go to the fishing place ... sometimes if a person does not tell him, the one will have a poor catch". This means that to become a member of the village, having a good harvest was not dependent on luck, type of fishing gear used, or even the physiological features of the water body, but rather the influence of this institution on everyday life.

From the research site, most elders told the others of their beliefs that were related to wetland conservation and the use of natural resources in the wetland.

Based on the interviews within the village, Table 5 shows the codes of ethics that were still practiced, although some indigenous people had attempted to break free of the habits created by this belief system. Some villagers showed obvious signs of receiving punishment and were believed to have bad luck. In fact, the majority seemed to frown on the system of many deities, and would be openly considered an adherent to this traditional belief system. Judging from the finding, in keeping the institutions, there were beneficial outcomes that seemed important and perhaps suppressed the differences in the belief system. Therefore, even though someone did not participate in the worship or perform rituals for the guardian spirit in deference to the ideology of animism, they still wanted to maintain the social connection with their community. 
Table 5. Indigenous beliefs related to taboos.

\begin{tabular}{lll}
\hline \multicolumn{1}{c}{ Taboo. } & \multicolumn{1}{c}{ Rationale } & \multicolumn{1}{c}{ Punishment } \\
\hline $\begin{array}{l}\text { 1. Cutting or burning Chaiyawan } \\
\text { trees (Mitragyna diversifolia (Wall. } \\
\text { ex G. Don) Havil). }\end{array}$ & These trees belong to Pu Ta Sung. & $\begin{array}{l}\text { Pu Ta Sung will bring mental } \\
\text { illness and quarrels amongst } \\
\text { family members. }\end{array}$ \\
\hline $\begin{array}{l}\text { 2. Stealing from other fish trappers } \\
\text { in the wetland. }\end{array}$ & $\begin{array}{l}\text { Pu Ta Sung ensures the security of } \\
\text { their trapping and fishing tools. }\end{array}$ & $\begin{array}{l}\text { Pu Ta Sung will bring illness and } \\
\text { bad luck. }\end{array}$ \\
\hline $\begin{array}{l}\text { 3. Killing Indochinese rat snakes } \\
\text { (Ptyas korros), wild birds, and } \\
\text { turtles in the wetland. }\end{array}$ & $\begin{array}{l}\text { These animals are symbolic of } \\
\text { holiness, and killing them can } \\
\text { contribute to sin. }\end{array}$ & $\begin{array}{l}\text { Pu Ta Sung will cause the one to } \\
\text { die early. }\end{array}$ \\
\hline $\begin{array}{l}\text { 4. Fishing during the early } \\
\text { rainy season. }\end{array}$ & $\begin{array}{l}\text { The villagers should ask for } \\
\text { permission from the guardian } \\
\text { before fishing. }\end{array}$ & $\begin{array}{l}\text { Pu Ta Sung will punish by bring } \\
\text { bad luck to who brake permission. }\end{array}$ \\
\hline $\begin{array}{l}\text { 5. Entering the designated } \\
\text { sacred zone. }\end{array}$ & $\begin{array}{l}\text { Entering is regarded as an act of } \\
\text { disturbance to Pu Ta Sung, as it is } \\
\text { a place/home of Pu Ta Sung. }\end{array}$ & $\begin{array}{l}\text { It will bring some form of } \\
\text { mental illness. }\end{array}$ \\
\hline
\end{tabular}

Source: Authors' focus group discussions, 2013.

\subsection{Indigenous Beliefs and the Wetland}

The distribution of the three categories of the response variable showed that the natural resources in the wetland of Ban Don Deng were largely valued for extractive use (Table 6). In examining the socioeconomic attributes to the response, it was found that more men perceived the wetland as a source of livelihood than women. Also, the respondents in the age range of 40-49 had this perception more than those in other age brackets. In addition, the respondents who graduated from university or high school tended to have this perception compared to those who finished up with primary or secondary school. As for the perception of the wetland as a place of worship, it was found that those who had not graduated from high school tended to have this perception, as well as those aged over 50 . During our interview, the elderly group said "Certain areas are forbidden; for example, the sacred area in the forest and sacred wetland. In the western of the lake and in front of the house of guardian spirit is a sacred place. The resources around the sacred place he protected for our villagers' use because these places are an inheritance from our ancestors".

The distribution suggests that those who were educated and were below 50 years of age tended to perceive the wetland resources as a source of livelihoods, while the rest tended to perceive the wetland resources as a place of worship.

Table 6. Distribution of perceived significance of the wetland in Ban Don Deng by socioeconomic category $(n=158)$.

\begin{tabular}{lcccccccccccc}
\hline & \multicolumn{4}{c}{ Sex } & \multicolumn{3}{c}{ Educational Attainment } & & \multicolumn{2}{c}{ Age Bracket } \\
\cline { 2 - 12 } Response Category & $n$ & Male & Female & $\begin{array}{c}\text { Primary } \\
\text { School }\end{array}$ & $\begin{array}{c}\text { Secondary } \\
\text { School }\end{array}$ & $\begin{array}{c}\text { High } \\
\text { School }\end{array}$ & Univ. & $\mathbf{2 0 - 2 9}$ & $\mathbf{3 0 - 3 9}$ & $\mathbf{4 0 - 4 9}$ & $\mathbf{5 0 - 5 9}$ & $\begin{array}{c}\mathbf{6 0} \text { and } \\
\text { Above }\end{array}$ \\
\hline $\begin{array}{l}\text { A source of } \\
\text { livelihoods }\end{array}$ & 71 & $61.9 \%$ & $38.1 \%$ & $0.0 \%$ & $1.4 \%$ & $52.1 \%$ & $46.5 \%$ & $25.4 \%$ & $8.4 \%$ & $57.8 \%$ & $2.8 \%$ & $5.6 \%$ \\
\hline A place of worship & 76 & $51.3 \%$ & $48.7 \%$ & $32.9 \%$ & $51.3 \%$ & $13.2 \%$ & $2.6 \%$ & $5.3 \%$ & $3.9 \%$ & $2.6 \%$ & $51.4 \%$ & $36.8 \%$ \\
\hline $\begin{array}{l}\text { An inheritance from } \\
\text { my ancestors }\end{array}$ & 11 & $45.4 \%$ & $54.6 \%$ & $9.1 \%$ & $0.0 \%$ & $54.6 \%$ & $36.3 \%$ & $0.0 \%$ & $54.5 \%$ & $0.0 \%$ & $0.0 \%$ & $45.5 \%$ \\
\hline
\end{tabular}

Source: Authors' field survey, 2015.

Table 7 shows the multinomial logit regression result for attributes of perceived significance of the wetland in Ban Don Deng regarding the likelihood of perceiving the wetland as a source of livelihood in comparison with the perception as an inheritance from ancestors; the negative and significant coefficient of age $\geq 60$ dummy indicates that elderly people were more likely to have the 
latter perception of the wetland. Moreover, the positive and significant coefficient of the university dummy indicates that university graduates were more likely to have the former perception of the wetland. Regarding the likelihood of perceiving the wetland as a place of worship in comparison with the perception as an inheritance from ancestors, the negative and highly significant coefficient of the university dummy indicates that university graduates were less likely to have the former perception of the wetland. These regression results more or less confirm the descriptive result in Table 6 . In other words, it was proven that those who were more educated and/or younger had a greater tendency to view the wetland resources from the practical perspectives rather than from the spiritual perspectives.

Table 7. Multinomial logit regression result for attributes of perceived significance of the wetland in Ban Don Deng.

\begin{tabular}{|c|c|c|c|}
\hline Variable & Coefficient & Z-Statistic & $p$-Value \\
\hline \multicolumn{4}{|l|}{ A source of livelihoods } \\
\hline Women dummy & -0.849 & -1.16 & 0.247 \\
\hline Age $40-59$ dummy & 16.619 & 0.02 & 0.984 \\
\hline Age $\geq 60$ dummy & $-1.681 *$ & -1.87 & 0.062 \\
\hline University dummy & $1.679 * *$ & 2.00 & 0.046 \\
\hline Constant & 0.853 & 1.13 & 0.258 \\
\hline \multicolumn{4}{|l|}{ A place of worship } \\
\hline Women dummy & -0.200 & -0.25 & 0.782 \\
\hline Age 40-59 dummy & 16.820 & 0.02 & 0.984 \\
\hline Age $\geq 60$ dummy & 1.783 & 2.23 & 0.260 \\
\hline University dummy & $-2.653^{* * *}$ & -2.66 & 0.008 \\
\hline Constant & 0.587 & 0.79 & 0.427 \\
\hline Number of observations & \multirow{3}{*}{\multicolumn{3}{|c|}{$\begin{array}{l}158 \\
94.15(p=0.0000) \\
0.3321\end{array}$}} \\
\hline Likelihood Ratio $\mathrm{Chi}^{2}(8)$ & & & \\
\hline Pseudo $\mathrm{R}^{2}$ & & & \\
\hline
\end{tabular}

\subsection{Factors Influencing Natural Resource Management (NRM) and Ecological Conservation}

The study collected information as to the factors influencing indigenous people's NRM and conservation of the environment. The following three subsections describe and discuss those factors.

\subsubsection{Traditional Beliefs}

Our study revealed that the beliefs of the indigenous people were linked to community NRM, such as the belief that $\mathrm{Pu}$ Ta spirit worship was specifically aimed at the moral side of nature conservation and resources management. This mechanism influenced the behavior of the people in the society as they believed that the spirit owned the natural resources. The only way to access natural resources was to ask for permission from $\mathrm{Pu}$ Ta's spirit. This spiritual conduct meant that anything prohibited was a taboo. Taboos are part of the system of managing local resources based on the belief in the $\mathrm{Pu}$ Ta spirit that controls the behavior and the practicing guidelines in managing the system of natural resources of the indigenous people. Many actions were prohibited so as to control people or instill fear of punishment from the holy being, which was regarded as a power beyond the control of humans. It was believed that if the indigenous people followed the rules strictly, then the spirit of the ancestors would respond to the want of the community and bring rain, abundance, luck, or a satisfactory outcome.

The prohibitions found in using the Nhongchaiwan wetland from Ban Don Daeng can be separated into two groups. The first group concerns the management and the conservation of natural resources such as forbidding people to cut the Chaiwan trees in the middle of the wetland of the village, to hunt animals on Buddhist Holy Day, or to invade or govern the land. The second group 
concerns the morality of the community, such as the prohibition to speak against the spirit and the holy spirit, and to destroy, make dirty, or damage the area of the protector, a prohibition, which was believed to be punishment by the spirit and could be explained by the power beyond humans, or the power of the holiness [32].

Generally, the villagers communicated with the Pu Ta spirit via Chao Chum: the sorcerer of the spirit. His duties involved channeling between the spirit and the villagers. Chao Chum might have to visit the people who infringed and notify them of the wrath of the spirit as the leader of spiritual perception. Chao Chum has the power of statement among the villagers.

When the people knew they had done something wrong, they had to apologize to the Pu Ta spirit by worshipping, making offerings, or performing a ritual. Thus, the Tai Yo people believed that the Pu Ta spirit from their ancestors had the power and holiness to bless villagers who followed the regulations and trust in faith to be rewarded with good luck or fortune. Another belief about the auspicious time calculation may be due to the behavior of accessing natural resources based on timing [33,34].

According to the findings from in-depth interviews of our study, the belief in the Pu Ta spirit and auspicious time calculation influenced the behavior of the indigenous people, and controlled the use of natural resources in the Nongchaiyawan wetland. This was supported by the rules and legends about the punishment of indigenous people who committed a wrongdoing. These indicate the traditional beliefs of the community, and the acceptance of the indigenous people of the power of the $\mathrm{Pu} \mathrm{Ta}$ spirit. Their belief is applied and used as traditional knowledge in the present day, so that they can claim collective ownership of the wetland, caring for their natural resources. The indigenous people believed in the $\mathrm{Pu}$ Ta spirit, and they participated in the life of the community. Thus, through the accumulated experiences of the indigenous people and their beliefs, Ban Don Daeng beneficially influenced the social culture and the environments at the community level [35].

Although the result from the village headman's interview pointed to the fact that some indigenous people in the village disobeyed the spirit, the villagers managed to solve the problem through mediation by the elders, or by parents instructing younger people. This community had high social capital; as a result the younger community members obeyed the elders. Table 5 showed the mechanism of punishing codes for regulating the use of natural resources in the wetland, which transformed into rules and institutions. The linkage between community rules, taboos, and ecological behavior indicates that the indigenous beliefs induce the community to appreciate the right to use the wetland, and to contribute to natural resources conservation and a sufficiency in income from the wetland (Table 8).

Table 8. Benefits from the forest in the Lower Songkran River Basin $(n=158)$.

\begin{tabular}{|c|c|c|c|c|c|c|}
\hline \multirow[t]{2}{*}{ Use } & \multicolumn{3}{|c|}{$\begin{array}{c}\text { Rainy Season } \\
\text { (June-November) }\end{array}$} & \multicolumn{3}{|c|}{$\begin{array}{c}\text { Dry Season } \\
\text { (December-May) }\end{array}$} \\
\hline & Products & & Benefits & Products & & Benefits \\
\hline $\begin{array}{l}\text { Gathering wild } \\
\text { vegetables for sale } \\
\text { and consumption }\end{array}$ & $\begin{array}{l}\text { Heimiell retispora, } \\
\text { Termitomyces } \\
\text { fuliginosus, } \\
\text { Azadirachta indica, } \\
\text { Planchonia valida }\end{array}$ & - & $\begin{array}{l}3-6 \\
\text { times/year } \\
\text { Each sale } \\
\text { generates } \\
\text { USD 3-5 }\end{array}$ & $\begin{array}{l}\text { Melientha suavis, } \\
\text { Cratoxylum } \\
\text { formosum, Senna } \\
\text { siamea, and } \\
\text { Zingiber zerumbet }\end{array}$ & - & $\begin{array}{l}3-4 \\
\text { times/year } \\
\text { Each sale } \\
\text { generates } \\
\text { USD 3-4 }\end{array}$ \\
\hline $\begin{array}{l}\text { Gathering insects } \\
\text { and animals for } \\
\text { sale and } \\
\text { consumption }\end{array}$ & $\begin{array}{l}\text { Melolontha } \\
\text { melolontha, } \\
\text { Occidozyga lima, } \\
\text { Hoplobatrachus } \\
\text { rugulosus, } \\
\text { Calotes versicolor }\end{array}$ & - & $\begin{array}{l}5 \text { times/week } \\
\text { Each sale } \\
\text { generates } \\
\text { USD 3-5 }\end{array}$ & $\begin{array}{l}\text { Leiolepis belliana, } \\
\text { Calotesversicolor, } \\
\text { Cicadidae, eggs and } \\
\text { pupae of Oecophylla } \\
\text { smaragdina Fabricius }\end{array}$ & - & $\begin{array}{l}7 \text { times/week } \\
\text { Each sale } \\
\text { generates } \\
\text { USD 2-3 }\end{array}$ \\
\hline
\end{tabular}


From the interviews with the indigenous people in Ban Don Daeng, we found that in 1997 the government implemented a policy to develop public utilities and an industrial capitalism system. Villagers saw examples of the government's development failures from communities nearby. They also saw that the ecosystem was being destroyed in nearby communities. However, the indigenous people maintained their environment, the biodiversity of the flora and fauna, and the genetic resources in their area [36]. The villagers had the pride and confidence to independently preserve and manage their natural resources. Thus, our results suggest that the belief in the power of the Pu Ta spirit was a strong force that drove the community to manage the natural resources and the spiritual wetland.

\subsubsection{Property Rights to the Wetland}

The rights of the indigenous people originated from their culture, way of life, and ideology closely related to the social system of the community. In the same way, the indigenous people in Ban Don Daeng defined their rights to access and use the wetland natural resources in the community, given the economic, political, societal, and environmental conditions. The belief and other legends related to the spirit of the ancestors fostered the tribal people's control over the natural resources throughout the history of the village [37]. The history of the indigenous people in Ban Don Daeng has been firmly related to such property rights. The shrine of $\mathrm{Pu} \mathrm{Ta}$ was in the middle of Nhongchaiwan wetland before the tribe moved to the riverbank, according to our interviews with the people of Ban Don Daeng in 2014. Thus, to date, the Ban Don Daeng indigenous people have united and empowered themselves with the rights to own, access, and use the natural resources in the wetland, with the power of the spirit protecting and managing their wetland [38].

\subsubsection{Benefits from the Wetland}

The wetland is a place the community uses for social activities, and it generates income for the whole community. The wetland is also a source of biodiversity, providing food and herbs. The island with a floating forest is an important place for fish breeding, providing a shelter for fish to lay eggs as they migrate in the flood season from the Mekong River. This type of resource is useful for the indigenous people and other communities not only in the LSRB but also in the Lower Mekhong Greater Sub-Region. Table 8 presents an example of benefits arising from the non-timber forest products in the LSRB.

\subsection{Implications of the Findings for Natural Resources Management}

Our quantitative result showed that relatively old indigenous people and a less educated population tended to have inherited the spiritual beliefs and practices of rituals, worships and taboos (Tables 6 and 7), which had formed local institutions due to the traditional use of the wetland as a mechanism to regulate indigenous people's behaviors and actions. Furthermore, the wetland became the last and largest in Cephalanthus tetrandra freshwater swamp forest in north-east Thailand and generated sources of income for the holy village (Table 8).

However, the quantitative result (Tables 6 and 7) also implied that younger generations of indigenous people viewed the wetland as a source of livelihoods, primarily taking into account the economic benefits of it, which might lead to an extinction of traditional beliefs and a degradation of natural resources in the long run. In this context, retention of some traditional beliefs and cultural practices of the indigenous people would be important. The strong existing reverence among the local rural population to local natural resources should be maintained and supported, particularly through education at schools with a view to enhancing nature conservation and sustainable wetland resource management. Currently, these topics are taught as part of the subjects of fundamental science and local culture at the Ban Don Deang village's primary school, which aims to educate local children about their own cultures, heritages and values, as supported by the Thai government.

The results were aligned with those of a previous report [39] that indigenous beliefs and rich traditional practices of indigenous cultures that deemed some parts of nature as the home of ancestral 
spirits in the form of shrines, groves, and sacred areas influenced the behavior of the indigenous people toward their environments. Natural environments often include objects such as trees and animals that serve people's basic needs as well as being recognized as abodes of spirits [3,40]. Traditionally, some plants and animals within the worship area of the wetlands tended to be protected, and these practices encouraged natural resources management and conservation through the use of traditional beliefs, institutions, and cultural practices. These local management systems have evolved over time and have often proved more effective and sustainable than other forms of management [37,38,41].

Such indigenous beliefs and practices have contributed to NRM systems. It is worth emphasizing that traditional institutions play an important role in ensuring that violators are punished, as illustrated by Tsusaka et al. [42]. Collective management of these natural resources is predicated on religions, beliefs, morality, norms and cultural practices. The allegiance to these beliefs and practices has, over time, influenced natural resource management through the engagement of taboos, respect for sacred areas, and rules and institutions [37]. Therefore, indigenous beliefs can also be engaged with as both a starting point for local options and broad guidelines for the management of natural resources. The sacred areas of the indigenous people are treated specially or, in the case of whole ecosystems, are restricted zones where institutions and practices are maintained. The indigenous people in the studied village generally acknowledge and respect the institutions and restrictions of the family within the emblem that embodies a spirit. This is an example of indigenous people that respect the traditional history and value system and would not enter the restricted areas without permission from the family. This has implications for recognizing and building the capacity of the existing institutions of these societies in terms of managing natural resources. Hence, within the surroundings of this wetland, the required rules of conduct of the belief system must be followed.

\section{Conclusions and Recommendations}

Indigenous people have lived in the Lower Songkhram River Basin (LSRB) for two centuries. They have beliefs in and respect for the holy spirit of the nature, as reflected in their lifestyle and wisdom. The way of life and traditional ecological knowledge of the indigenous people in the LSRB have been based on the belief in the Pu Ta spirit, which led to the creation of the sacred Don Pu Ta area. Traditional spiritual beliefs in ancestral spirits are closely related to various aspects of environmental management in the LSRB. The assertion that a traditional community's reverence to the natural habitat is a significant factor contributing to sustainable local nature resource management was substantiated during the field work of the project.

Furthermore, indigenous people can claim ownership of the wetland, and accordingly they have the rights to access and use the natural resources. Hence, they utilize these property rights to negotiate with the government, asking for favorable regulations to preserve the ecology of the wetland. This demonstrates the cultural path of the indigenous people, who have a strong desire to preserve and conserve the biodiversity in their local ecosystems. Consequently, indigenous people should be granted the power to participate in the design of natural resource management regulations so that the community will retain the right to control and conserve the ecological habitat in their own environments through the inclusion of their traditional beliefs and rights in the local government master plan to protect their cultural forms, which value the importance of the holy spirits of the environments [43-45]. In particular, nowadays the LSRB has been nominated as a protected area under the Ramsar Convention on Wetlands of International Importance as a result of joint efforts by the local government, the HSBC-Thailand bank, and the Worldwide Fund for Nature-Thailand (WWF). Thus, policy makers should engage with local beliefs in order to achieve sustainable resource management, and therefore such practices should be recognized and included in the government's policies on natural resources management in locations, where indigenous people have lived for generations. The practices based on indigenous beliefs will lead to the protection not only of Nonnchaiwan wetland but of the $92 \mathrm{~km}$ stretch of the Songkhram River and 34,000 rai (5440 hectares) of basin. Eventually, more than 240,000 people and 49 communities would benefit from the designation [46-48]. 
Arguably, traditional cultural beliefs and methods can be leveraged to solve environmental problems, both at the operational level in north-east Thailand and at the national or Asian regional policy level. This should be the subject for further research.

Author Contributions: P.C. designed the research, collected, and analyzed the data and drafted the manuscript. N.S. worked on the flow, organizational structure, discussions, conclusion, and correspondence. C.G. contributed to early conceptualization, improving the clarity of the research and revising the manuscript. J.K.M.K. and T.W.T. substantially contributed to improvement during the resubmission process.

Acknowledgments: This research was sponsored by Nakhon Phanom University and the Asian Institute of Technology (AIT).

Conflicts of Interest: The authors declare that there is no conflict of interest regarding the publication of this article.

\section{References}

1. Kandari, L.S.; Bisht, V.K.; Bhardwaj, M.; Thakur, A.K. Conservation and management of sacred groves, myths and beliefs of tribal communities: A case study from North-India. Environ. Syst. Res. 2014, 3, 16. [CrossRef]

2. Mukul, S.A.; Rashid, A.M.; Uddin, M.B. The role of spiritual beliefs in conserving wildlife species in religious shrines of Bangladesh. Biodiversity 2012, 13, 108-114. [CrossRef]

3. Udgaonkar, S. The recording of traditional knowledge: Will it prevent "bio-piracy"? Curr. Sci. 2002, 82, 413-419.

4. Hortle, K.G.; Suntornratana, U. Socio-Economics of the Fisheries of the Lower Songkhram River Basin, Northeast Thailand; MRC Technical Paper No. 17; Mekong River Commission: Vientiane, Laos, 2008.

5. Cox, M.; Villamayor-Tomas, S.; Hartberg, Y. The role of religion in community-based natural resource management. World Dev. 2014, 54, 46-55. [CrossRef]

6. Ntiamoa-Baidu, Y. Indigenous vs. Introduced BIODIVERSITY Conservation Strategies: The Case of Protected Area Systems in GHANA; Biodiversity Support Program; Yale University Press: New Haven, CT, USA, 1995.

7. Appiah-Opoku, S.; Hyma, B. Indigenous Institutions and Resource Management in Ghana; The University of Waterloo: Waterloo, ON, Canada, 1999.

8. Atkinson, Q.D.; Bourrat, P. Beliefs about God, the afterlife and morality support the role of supernatural policing in human cooperation. Evol. Hum. Behav. 2011, 32, 41-49. [CrossRef]

9. Kettate, B. The Ancestral Spirit Forest (Don Pu Ta) and the Role Behavios of Elders (Thao Cham) in Northeastern Thailand. J. Siam Soc. 2000, 88, 96-110.

10. Barsh, R.L. Indigenous peoples and the UN Commission on Human Rights: A case of the immovable object and the irresistible force. Hum. Rights Q. 1996, 18, 782. [CrossRef]

11. Lebbie, A.; Guries, R.P. The Role of Sacred Groves in Biodiversity in Sierra Leone; Ohio University Press: Athens, $\mathrm{OH}, \mathrm{USA}, 2008$.

12. Schoffeleers, J.M. Guardians of the Land: Essays on Central African Territorial Cults; Mambo Press: Harare, Zimbabwe, 1978.

13. Gadgil, M.; Berkes, F; Folke, C. Indigenous knowledge for biodiversity conservation. Ambio 1993, 22, 151-156.

14. Chikwanha, V.T. The role of indigenous knowledge in management of forest resources in Mugabe Area, Masvingo. Zimbabwe. J. Sustain. Dev. Afr. 2011, 13, 132-141.

15. Ayong, F.M. Environmental awareness and management in Pre-Colonial Zimbabwe. J. Geogr. Res. 2007, 2, 98-111.

16. Penth, H. A Brief History of Lan Na: Civilizations of Northern Thailand; Silkworm Books; Mekong Press: Chiang Mai, Thailand, 1994.

17. Verschuuren, B.; Furuta, N. (Eds.) Asian Sacred Natural Sites: Philosophy and Practice in Protected Areas and Conservation; Routledge: Abington, UK, 2006.

18. Anh, H.V.; Pham, T.V. Link between Spiritual Forest and Forest Conservation: A Case Study in Noong La Village, Son La Province, Vietnam. Asia-Pacific Forum for Environment and Development. 2005. Available online: https://www.researchgate.net/publication/315891489_Link_between_Spiritual_Forest_ and_Forest_Conservation_A_Case_Study_in_Noong_La_village_Son_La_Province_Vietnam (accessed on 3 August 2018). 
19. Aniah, P.; Aasoglenang, A.T.; Bonye, S.Z. Behind the myth: Indigenous knowledge and belief systems in natural resource conservation in North East Ghana. Int. J. Environ. Prot. Policy 2004, 2, 104-112. [CrossRef]

20. Leblond, J.P. Population Displacement and Forest Management in Thailand; Canada Research Chair in Asian Studies, Université de Montréal: Montréal, QC, Canada, 2010.

21. Sretthachua, C.; Pitakthepsombut, R.; Niyomchat, W. Tai Baan Research Network of Lower Songkhram Basin. Tai Baan Research on the Ecology and History of the Seasonally Flooded Forest of the Lower Songkhram River Basin MWBP, Vientiane, Lao PDR. 2005. Available online: www.mekongwetlands.org/common/ download/IUCNT_ThaiBaanResearch.pdf (accessed on 3 August 2018).

22. Kanlaya, M.; Poolsap, S. The Last and Largest of Cephalanthus Tetrandra Freshwater Swamp Forest in Northeast Thailand: Natural Resource Appreciation and Management of Local Community. Int. J. Agric. Technol. 2016, 12, 523-532.

23. Boonyaratpalin, M.; Kohanantakul, K.; Sricharoendham, B.; Chittapalapong, T.; Termvidchakorn, A.; Thongpun, W.; Kakkaew, M. Ecology Fish Biology and Fisheries in the Lower Songkhram River Basin; Office of Fisheries Technical Advisor; Department of Fisheries: Chatuchak, Thailand, 2002; p. 191.

24. McCaskill, D.N.; Līprīchā, P.; He, S. Living in a Globalized World: Ethnic Minorities in the Greater Mekong Subregion; Silkworm Books; Mekong Press: Chiang Mai, Thailand, 2008.

25. Ryan, G.W.; Bernard, H.R. Techniques to Identify Themes. Field Methods 2003, 15, 85-109. [CrossRef]

26. Patai, D.; Gluck, S.B. Women's Words: The Feminist Practice of Oral History; Routledge: Abington, UK, 1999.

27. Schwartz, B. Memory and the practice of commitment. In Qualitative Sociology as Everyday Life; Sage: Newcastle upon Tyne, UK, 1999; pp. 56-79.

28. Miles, M.B.; Huberman, A.M. Qualitative Data Analysis: An Expanded Sourcebook; Sage: Newcastle upon Tyne, UK, 1994.

29. Hosmer, D.W., Jr.; Lemeshow, S.; Sturdivant, R.X. Applied Logistic Regression; John Wiley \& Sons: Hoboken, NJ, USA, 2013.

30. Neupane, R.P.; Sharma, K.R.; Thapa, G.B. Adoption of agroforestry in the hills of Nepal: A logistic regression analysis. Agric. Syst. 2002, 72, 177-196. [CrossRef]

31. Donati, L.; Turrini, M.C. An objective method to rank the importance of the factors predisposing to landslides with the GIS methodology, application to an area of the Apennines (Valnerina, Perugia, Italy). Eng. Geol. 2002, 63, 277-289. [CrossRef]

32. Kraft, M.G. Understanding Spiritual Power: A Forgotten Dimension of Cross-Cultural Mission and Ministry; Wipf and Stock Publishers: Eugene, OR, USA, 2003.

33. Haas, P.M. Obtaining International Environmental Protection through Epistemic Consensus. In Global Environmental Change and International Relations Palgrave Macmillan; Palgrave Macmillan: London, UK, 1992; pp. 38-59.

34. Ramaprasad, A.; Prakash, A.N. Emergent project management: How foreign managers can leverage local knowledge. Int. J. Proj. Manag. 2003, 21, 199-205. [CrossRef]

35. Stern, P.C.; Dietz, T.; Abel, T.; Guagnano, G.A.; Kalof, L. A value-belief-norm theory of support for social movements: The case of environmentalism. Hum. Ecol. Rev. 1999, 6, 81-97.

36. Ostrom, E.; Schlager, E. The Formation of Property Rights in: Rights to Nature: Ecological, Economic, Cultural and Political Principles of Institutions for the Environment; Island Press: Washington, DC, USA, 1996; pp. 127-156.

37. Abu, A.; Millar, D. Land, Natural Resource and Spirituality; Policy Implication on Rural Livelihood in Northern Ghana; CECIK: Bolgatanga, Ghana, 2004.

38. Utkarsh, G.; Gadgil, M.; Rao, P.R.S. Intellectual property rights on biological resources: Benefiting from biodiversity and people's knowledge. Curr. Sci. 1999, 77, 1418-1425.

39. Eneji, C.V.O.; Ntamu, G.U.; Unwanade, C.C.; Godwin, A.B.; Bassey, J.E.; Willaims, J.; Ignatius, J. Traditional African Religion in Natural Resources Conservation and Management in Cross River State, Nigeria, Environment and Natural Resources Research; Canadian Center of Science and Education: North York, ON, Canada, 2012.

40. Dorm-Adzobu, C.; Ampadu-Agyei, O.; Veit, P.G. Religious Beliefs and Environmental Protection: The Malshegu Sacred Grove in Northern Ghana; WRI: Washington, DC, USA; Acts Press, Africa Centre for Technology Studies: Nairobi, Kenya, 1991.

41. Tupper, M. Marine reserves and fisheries management. Science 2002, 295, 1233. [CrossRef] [PubMed]

42. Tsusaka, T.W.; Kajisa, K.; Pede, V.O.; Aoyagi, K. Neighborhood Effects and Social Behavior: The Case of Irrigated and Rainfed Farmers in Bohol, the Philippines. J. Econ. Behav. Organ. 2015, 118, 227-246. [CrossRef] 
43. Thailand's Last Untouched Mekong Tributary. The Nation. Available online: http://www.nationmultimedia. com/detail/national/30346983 (accessed on 5 June 2018).

44. Devereux, P. The Sacred Place: The Ancient Origins of Holy and Mystical Sites; Cassell: London, UK, 2000.

45. Swamy, P.S.; Kumar, M.; Sundarapandian, S.M. Spirituality and sacred groves in Tamil Nadu, India. Unasylva. 2003. Available online: http://www.fao.org/tempref/docrep/fao/005/y9882e/y9882e10.pdf (accessed on 3 August 2018).

46. Khumsri, M.; Ruddle, K.; Shivakoti, G.P. Rights and conflicts in the management of fisheries in the Lower Songkhram River Basin, Northeast Thailand. Environ. Manag. 2009, 43, 557-570. [CrossRef] [PubMed]

47. Blake David, J.H. The Three Dimensional Commons of the Lower Songkhram River Basin Wetlands, Thailand. In Proceedings of the Governing Shared Resources: Connecting Local Experience to Global Challenges, the Twelfth Biennial Conference of the International Association for the Study of Commons, Cheltenham, UK, 14-18 July 2008.

48. Kuaycharoen, P. Common Property Rights Regimes: Dynamics of Management of Freshwater Fisheries Resources in the Communities of the Lower Songkhram River Basin; Thammasat University: Bangkok, Thailand, 2008; p. 169.

(C) 2018 by the authors. Licensee MDPI, Basel, Switzerland. This article is an open access article distributed under the terms and conditions of the Creative Commons Attribution (CC BY) license (http:/ / creativecommons.org/licenses/by/4.0/). 